Chapter 3 /

\title{
Greek Tragedy: Writing, Truth, and the Representation of the Self
}

I

When tragedy is born in Athens around 500 B.C., the city creates in its midst the civic space in which it can look at itself in the mirror of the ancient myths. Theatron, "theater," is a space for beholding, derived from the verb theaomai, to behold with wonder. This narrative form is the most vivid possible representation of myth in Greek culture. It is also a form of mythic representation which highlights all the tensions, contradictions, and problems that arise when the Athenians adapt to their new democracy the aristocratic legends of the past: tales about kings and heroes, about ancient families that claim descent from the gods, and about the hereditary curses handed down in the bloodlines of these families. ${ }^{1}$ But throughout Greece in the course of the sixth and fifth centuries, social changes (including the increasing use of writing) and consequent changes in the role of the poet bring concomitant changes in the character and function of mythic narration. 2

A French version of some parts of this essay, in a different form and with a different emphasis, appears as the introduction to my La musique du Sphinx: Structure, mythe, langage dans la tragédie grecque (La Découverte, Paris, forthcoming). I thank the John Simon Guggenheim Memorial Foundation for a fellowship in $1981-82$, which supported the research for this study. I am grateful to Froma Zeitlin of Princeton University for friendly criticism and advice.

I. See Jean-Pierre Vernant, "Tensions et ambiguïtés dans la tragédie grecque," in Vernant and P. Vidal-Naquet, Mythe et tragédie (Paris I 972) 24ff.; also Vidal-Naquet's chapters on the Oresteia and the Philoctetes in the same volume, especially I $49 \mathrm{ff}$. and I $68 \mathrm{ff}$.

2. For the changing role of the poet in the archaic period, see J. Svenbro, La parole 
In fifth-century Athens, writing enables the democratic polis to see itself in a new perspective and to claim for its contemporary existence, despite its ideology of change and innovation, a patrimony of glorious tradition analogous to the myths of the ancient aristocratic families. The written histories of Herodotus and to a greater degree of Thucydides, as Diego Lanza has argued, ${ }^{3}$ are analogous to tragedy in that they create for the democracy a mirror in which Athenians can contemplate the deeds of their city and preserve in memory the words of its leaders. These speeches, now condensed into definitive form and fixed as part of the history's eternal possession, ktêma es aiei, are not only the record of what has impelled the city to its actions but also the verbal expression of its elusive consciousness, its essential character.

The notion of the unity of Greek culture stretching in a more or less unbroken line from Homer to Aristotle is deeply inbedded in the historical imagination of the modern world, from its early exponents, Lessing, Herder, and Winckelmann, to the historical synthesizing of Wilamowitz. But in the last few decades this unitary structure has suffered multiple fractures. The most recent attack has come from the work of Eric Havelock, whose studies of the implications of literacy and preliteracy over the last twenty years have forced us to reexamine some of the massive changes in concerns, outlook, and expression brought about by the transition from an oral to a literate culture. 4

Havelock himself has paid remarkably little attention to tragedy and only recently included it within his reexamination of the intellectual history of early Greece. 5 While aware of tragedy's position be-

et le marbre (Lund 1976), which references to earlier literature. For archaic poetry in the perspective of an oral culture, see B. Gentili, "Aspetti del rapporto poeta, committente, uditorio nella lirica corale greca," Studi Urbinati 39 (1965) 70-88.

3. D. Lanza, Lingua e discorso nell' Atene delle professioni (Naples I979) 56; also 75 f.

4. E. A. Havelock, Preface to Plato (Cambridge, Mass. 1963), The Greek Conception of Justice (Cambridge, Mass. 1978), and essays collected as The Literate Revolution in Greece and Its Consequences (Princeton 1982).

5. Havelock, "The Oral Composition of Greek Drama," QUCC n.s. 6 (I980) 6II 3 (or Literate Revolution [note 4] 26I-3 I3). 
tween the oral and literate phases of Greek culture, he emphasizes the continuities of tragedy with the attitudes and style of oral poetry. The tragedian, according to his view, is a late manifestation of the oral poet, conveying communal and traditional wisdom. My purpose is to give more importance to the tensions inherent in tragedy as a literary form and to allow more importance to the radical departures from an oral tradition which are implicit in tragedy.

Tragedy is an oral performance, but one controlled by a written text. ${ }^{6}$ It is performed in the agonistic and ritual setting that characterizes most of early Greek literature. Unlike oral epic, however, tragedy is not recreated afresh on each occasion by the improvisatory art of the aoidos, the oral singer. If the plays were acted again after initial performance at the Dionysiac festival of the Lenaea or the Dionysia (a privilege allowed only to the plays of Aeschylus), they were not re-creations requiring a fresh inspiration and a new composition for that occasion, as in oral poetry, but the replication of a fixed text. ${ }^{7}$ In the fif th century the text serves primarily as the script for a performance. Tragedians do not seem to think of their work as intended for a reading public until the fourth century. 8

As the creator of a written text destined for oral performance, the tragic poet, unlike the oral singer, stands in a deferred relation to his work. Composition and performance no longer coincide; instead, there is an intermediate stage when the work is complete but unrealized. Indeed, a tragedian may have composed plays that were not

6. On tragedy and the development of writing see U. von Wilamowitz-Moellendorff, Einleitung in die griechische Tragödie, vol. I of his Euripides, Herakles (Berlin I 907) I 20-27; see in general Walter Ong, S. J., Orality and Literacy (London and New York I982) I48f. Comedy, though it allows for more improvisation in performance, also depends on a fixed text, and the development of comedy as a literary form postdates that of tragedy in fifth-century Athens.

7. For the difference between oral recreation and exact reproduction see A. B. Lord, The Singer of Tales (Cambridge, Mass. I960) chap. 6. He has reiterated how foreign is the notion of a fixed text in an oral culture in "The Influence of Fixed Text," To Honor Roman Jakobson 2 (The Hague and Paris I967) I I96-I 206, especially I 206. See also J. Goody, "Mémoire et apprentissage dans les sociétés avec et sans écriture," L'Homme I7 (I977) 29-\$2, especially 44. For recent discussion, with ample bibliography, see Bruno Gentili, “Oralità e scrittura in Grecia," in M. Vegetti, ed., Oralità scrittura spettacolo (Turin I983) 30-52.

8. Aristotle, Rhetoric 3.12, I4 I3bi2ff.; also Albin Lesky, Greek Tragedy, 3d ed., trans. H. A. Frankfort (London and New York 1967) 204. See also Aristotle, Poetics 26, I 462ai I-I7 and G. F. Else, Aristotle's Poetics: The Argument (Cambridge, Mass. I957) $635 f ., 640 f$. 
presented until months or years later. Tragedians might revise a play already presented, as Euripides did with his Hippolytus Veiled-a procedure that itself implies heavy reliance on writing in the mode of composition-or might revise a play that would then exist only as a written text, as seems to have happened in the case of Aristophanes' Clouds. ${ }^{9}$ Admittedly, a choral poet like Alcman composed songs that others would perform later; but such works were far shorter and less complex than a tragedy. The long compositions of Stesichorus that have recently come to light-the Jocasta fragment and the Geryoneis - are not certainly choral and seem much closer to oral epic in the smooth narrative flow, the simple and linear movement of the plot, and the elaboration of surface detail. 10

This division between the two stages in the production of a tragedy-text and performance-may have contributed to the distance from the mythical subject that the conflictual, open-ended, and questioning spirit of Greek tragedy demands. Instead of one-sidedly celebrating a local hero, as choral lyric tends to do, tragedy combines sympathetic participation with the presentation of different points of view, attitudes, and perspectives, no one of which is necessarily final or right. ${ }^{11}$ Hence Aeschylus can movingly depict the suffering of his audience's mortal enemies in the Persians, and Euripides can portray with compassion the defeated enemies of the Greeks in the $A n$ dromache, Hecuba, and Trojan Women.

It is also possible-though here we are in a realm of pure speculation-that this two-stage mode of production sensitizes the tragic poet to the two systems of communication and representation, verbal and visual, that his art involves: the power of visualization inherent in the image-making power of the word itself and the concrete act of visualization on the theatrical stage. The coexistence of verbal and visual representation unique to the theater involves, at nearly every point, dichotomy, contradiction, or paradox in the existence of truth.

9. It is widely agreed that the version of the Clouds handed down to us is the revised text of a play that may never have been performed: see K. J. Dover, Aristophanes, Clouds (Oxford I 968) lxxxff.

Io. On formulaic elements in Stesichorus see G. Vognone, "Aspetti formulari in Stesicoro," QUCC n.s. I2 (I982) 35-42, who sees in the style an intermediate stage between the oral, rhapsodic tradition and literate poetry. I should say that the former predominates.

I I. On this point see Alvin Gouldner, Enter Plato: Classical Greece and the Origins of Social Theory (New York and London I965) I I 4; also Vernant's "Tensions" (note I). 
The conflict between appearance and reality, what is seen and what is said, is of course a recurrent theme of Greek literature from its earliest beginning: the external, visual attractions of women's beauty are already dangerous in Hesiod's Pandora, and Homer's Odysseus is a master of lies and disguises. These tensions between the surface world that we see and the hidden truths that we do not are also explored by the philosophers, from Thales and Anaximander to Parmenides and the Atomists. Yet in tragedy the rift between seen and unseen truth acquires a more vivid representation through being enacted before our eyes, in the gestures and movements of living men in real space.

In early Greek society the poet is a "master of truth," the speaker of a discourse that derives validity from a set of culturally privileged narratives. 12 Homer invokes the Muses as his source of knowledge about the past (Il. 2.484-87). Hesiod relates how the Muses on Helicon give him a skepptron, a staff, emblem of authority, and breathed into him the power of song along with the knowledge of its capacity for both truth and falsehood (Theogony 26-34).13 By the late sixth century, however, that authority for truth has been secularized and internalized. Oral poetry-and I have in mind the Homeric poems in particular-gives us the sensation of the full presence of events: we feel that we have all the necessary details and that we possess that immediacy of foreground eioquently described by Erich Auerbach in the famous first chapter of Mimesis. Tragedy, based as it is on a written text, is full of elusive details, missing pieces, unexplained motives, puzzling changes of mood, decision, or attitude. Instead of the oral poet who tells us in person of the will of Zeus, we have the absent poet who has plotted out every detail in advance. And we have the feeling, at times, that we have been plotted against, that we are the victims of a calculated counterpoint between surface and depth, appearance and reality, seeming and being.

As the basis for bardic authority is reexamined in the critical spirit fostered by writing, authors need to shape another kind of narrative in order to lay claim to a discourse of truth. They need to tell a

I2. M. Detienne, Maîtres de vérité dans la Grèce archaï que (Paris I967).

I3. For recent discussion of the Muses in Homer and Hesiod, see W. Rösler, "Die Entdeckung der Fiktionalität in der Antike," Poetica I 2 (I980) 294-98, with further bibliography; also P. Pucci, Hesiod and the Language of Poetry (Baltimore and London I977) 8-44. 
different kind of story about themselves in order to support the truth that they claim to speak. Such, for instance is the journey of Parmenides, cast in the traditional form of a Homeric narrative and studded with phrases borrowed from the epic vocabulary. ${ }^{14}$ But Parmenides' traditional language serves only to set off the unique, mysterious quality of his journey and his destination. This poet is going not to a mythical land of Laestrygonians but to a realm of philosophical concepts, being and nonbeing. Such too is Thucydides' new story about himself, a story not about gods and Muses but about a "journey" of investigation, inquiry, strenuous examination, zētessis tês alètheias, "a searching out of truth" (Thucyd. I.20.3 and in general I.20-22).

The increasing literacy of the late fifth century, at least in Athens, 15 is one of several interrelated influences that tend to cut the discourse of truth loose from the communal, performative, and agonistic context of the archaic period and thereby to require the poet to reflect consciously on the source of truth or, in other words, on the kind of story that he has, implicitly, to tell about himself. Later poets, Callimachus and Theocritus, for example, do this almost as a matter of course and in the spirit of a self-conscious literary topos, to distinguish their art from that of their predecessors and contemporaries. 16

What is the implicit story of the tragic poet? It is no longer a tale of meeting Muses of gods (such as even Pindar still could tell). 17 The tragedian's story resembles perhaps that of Oedipus or Teiresias; it is the story of a double vision or a double language (dissai phōnai), of a

I4. Parmenides frag. 28 B I (D-K).

I5. For the growing importance of literacy in the last quarter of the fif th century see F. D. Harvey, "Literacy in the Athenian Democracy," REG 79 (I966) 585-635; E. G. Turner, Athenian Books in the Fifth and Fourth Centuries B.C. (London 1952); A. R. Burns, "Athenian Literacy in the Fifth Century," Journal of the History of Ideas 42 (I98I) 37I-87; Lanza, Lingua e discorso (note 3) 52-84, with the bibliography, 85-87; Giovanni Cerri, Legislazione orale e tragedia greca (Naples I979) 33-45, 65-74. On the upper limits of literacy among the Athenians, despite the number of inscriptions in the city, see Oddone Longo, Tecniche della comunicazione nella Grecia antica (Naples I98I) I 20, with I 25 n.20. It is part of Havelock's “oral" thesis that literacy be placed as late as possible in the fif th century, though he admits, rather reluctantly, the high literacy at the end of the century: Literate Revolution I $99 \mathrm{ff}$., especially $203 \mathrm{f}$.

I6. Cf. Theocritus 7. I23-30, especially I 28ff.; Callimachus, Aitia I, frag. I, 2 Iff., where the status of the fully literate poet is signaled by the presence of the writing tablet on his knees; also frag. 2.

17. For example, Pindar, Pyth. 8.56-60; Pyth. 3.77-79, with scholion I37b (Drachmann). 
backstage, of something hidden behind or beneath. 18 For Aristophanes, the verse by Euripides that reads "My tongue has sworn, but unsworn is my mind" (Hipp. 6I2) became almost a motto of that poet's form of tragedy, the ironic emblem of his defeat in the Frogs (I47I). In representing the visually concrete and physical exterior of the mythical character, tragedy heightens the mystery of his interior life. A self-conscious tragedian like Euripides repeatedly calls attention to the problem of representing, realizing, and verifying this interior realm.

In the fifth century the "graphic space" of alphabetic writing becomes a convenient metaphor for making visible the hidden realm of the emotional life. As the concretization into solid, stable, and visual form the fluid, invisible breath of the voice's "winged words," writing can represent the process of revealing what lies unseen within the mind. The most common of these graphic metaphors is that of the tablets of the mind, frequent in the tragedians, with the concomitant figure of unrolling or unfolding the interior secrets of the heart. $19 \mathrm{We}$ may include here Gorgias' figure of persuasion's "stamp" or "impression" upon the soul (tên psuchèn etupōsato) and his image of logoi that make things to be seen by "the eyes of opinion" (tois tēs doxés ommasin, Helen I3). Immediately afterward he speaks of the persuasive power of a logos that is "written with art" (technei grapheis). Then a few paragraphs later, describing the power of vision to arouse fear and desire, he uses another metaphor of writing: "So has vision inscribed [enegrapse] on thought the images [eikonas] of actual things seen" (Helen 17). He goes on to speak of painters (grapheis) and sculptors whose work brings pleasure and pain to the eyes. These visual metaphors, in turn, are intended as analogies for the force of eros as a quasi-corporeal power that enters the soul through the eyes.

At least two factors aid this association of writing and emotional interiority: the tendency in an oral culture to connect writing with private, secret, or deceitful communication (particularly of an erotic nature) and the importance that writing gives to vision, for the Greeks the most powerful stimulus to eros.20 Gorgias' theory of

18. Eur., Hipp. 925-3 I; Med. 516-I 9; HF 655-72. For the hidden in human life see Hipp. I9I-97 and the echoes later in Artemis' speech to Theseus, I287ff.

I9. E.g., Eur., Hipp. 985; cf. IT 793.

20. See, for example, R. C. Jebb, Sophocles, The Plays and Fragments, Part III, The Antigone (Cambridge I89I) on $795 \mathrm{ff}$. 
desire depends on this four-way association of writing, emotional life, eros, and vision. This graphic space, I shall suggest later, corresponds to the tragedians' new self-consciousness about what is going on behind and beneath, about what cannot be shown visually in the scenic action (the self as inner and hidden) and in the scenic language (the written text).

It would, of course, be a mistaken exaggeration to attribute to writing alone massive shifts of emphasis in Greek society which resulted from the interaction of many complex factors, economic, social, political, religious, and so on. The growing individualism of the fif th century, aided by the rationalism of the philosophers and the Sophists, the questioning of traditional values in the various crises of the Peloponnesian War, the gradual evolution of moral speculation over the previous century which included an increasing shift from "shame-culture" to "guilt-culture," all contribute to this concern with the inner self and the real nature of what we are. ${ }^{21}$ Nevertheless, the movement away from the face-to-face exchange of information in a small, village-type society, where everyone is familiar and defined by multiple nexuses of relationships, to the more abstractive, intellectual, and less personal mode of communicating information and ideas inherent in a literate culture accentuates the problem of self-knowledge and self-definition.22 Writing accompanies that increasing acknowledgement of complexity in the vision of self and world which marks the fif th century. The self defined by the physical externals of health, beauty, strength, and the opinion of others 23 is no longer adequate to a world view aware of irrational, invisible, mysterious forces within the individual and the governance of the universe.

Along with civic cult, epic and rhapsodic recitation, choral performances, and such other rituals of a dramatic nature as the Mysteries, drama depends upon a system of symbols and conventions to effect its mimesis of reality. The audiences that came to the first tragedies had long been schooled in a mode of thought that could "see" the Troad or Lemnos or Egypt in the circular orchestra of the theater or could accept the figure moving and speaking behind the mask as

2 I. For some speculation on these social changes see Gouldner (note i I) i I $3 f$., I $33 f$.

22. For the face-to-face mentality of village-type, oral societies see Longo, Tecniche della comunicazione (note I 5 ) I $3 \mathrm{ff}$.

23. See Gouldner (note I I) $98 \mathrm{ff}$., Iosff. 
Theseus, Heracles, or Agamemnon. But phonetic writing gives new force and simplicity of expression in everyday life to this process of conventionalized, symbolic representation. The increasing alphabetization of Athens as tragedy is developing, along with the critical spirit fostered in a literate society, sharpens awareness of the discrepancy between the imagined and the actual objects, just as phonetic writing sharpens awareness of the discrepancy between the alphabetic conventions and the tactile reality. 24 Hence the tragedians are interested not only in creating spectacles but in calling attention to their own power to create spectacles, to the system of conventions with which the form itself operates. We are familiar with such self-consciousness about the symbolic system of representation in late Euripidean plays, in the Helen and the Bacchae, 25 but the tendency is there even as early as Sophocles' Ajax, where the prologue seems to allude to the poet's illusionistic power as a kind of divine techne (86), enabling us the audience to be present as if unseen at events acted out before our eyes $(83-86): 26$

Athena. He could not see you, do not fear, even if you stand next to him.

Odysseus. How, if he sees with the same eyes?

Ath. I will darken his eyes, even though they see.

Od. Everything may come about with a god's devising craft.

\section{III}

Writing provides a fixed point of orientation and organization around which are focused the mental energies that are in an oral culture more diffused. The new skill appears not merely an intellec-

24. On the importance of phonetic writing as the source of a conventionalized symbol-system for tragedy see D. de Kerckhove, "Synthèse sensorielle et tragédie: L'espace dans Les Perses d'Eschyle," in Tragique et tragédie dans la tradition occidentale, ed. P. Gravel and T. J. Reiss (Montreal I983) 69-83, especially $75 \mathrm{ff}$., who seems to me to have isolated and exaggerated the importance of writing. Writing may have contributed to self-consciousness about the conventions, but the conventions themselves have older, deeper, and more diverse origins. See also his 1979 essay (note 28).

25. See below, notes 75 and 76 .

26. The discovery of Ajax's body at the climax of the play may also be calling attention to the technique of using the eccyclema to make visually powerful what would otherwise remain hidden: cf. $976-78$ and 890 with 9 I 5-I 7 . 


\section{Greek Tragedy: Myth and Structure}

tual technique but the sheer power of mind and eye (often closely associated by the Greeks, for whom to know is to see, as the two verbs have the same root, vid-). Simonides' new "art of memory" at the end of the sixth or beginning of the fif th century seems to have used visualization as its main component. 27 Thus the power of memory, instead of being attached to hearing and speech and therefore being oriented externally, toward others, is made part of visual experience and is oriented inwardly, toward oneself, toward silence and privacy. The metaphor, frequent in tragedy, of writing on the tablets of the mind identifies memory with something both visual and interior, a kind of interiorized writing (see below, section VIII). The literate revolution probably played an important role both in emphasizing visualization and in celebrating the power of mind, a recurrent theme in the classical period, from about 460 B. C. to the end of the century.

One of the most famous celebrations of this intellectual power is the Prometheus Bound of Aeschylus. Here, I think, we find an important indirect reflection of the new mode of mental organization implied in writing. The Titan, imprisoned and immobilized on his rock in the Caucasus in punishment for teaching the arts of civilization to mortals-including the arts of writing and counting-holds the center of the stage, an object of magnetic vision to all who approach him. ${ }^{28}$ Like the organizing force of a written text, this figure at the center of the spectacle is the source from which all the mental energy

27. See Cicero, De Orat. 2.86.354 and 2.87.357. See Gentili in Vegetti (note 7) 32. See also Kerckhove (note 28) 359-6I on Simonides and the "interiorization of a visual space" (36I).

28. After I had written this section, Professor Froma Zeitlin pointed out to me that a similar point had been made about the Prometheus by D. de Kerckhove, "Sur la fonction du théâtre comme agent d'intériorisation des effets de l'alphabet phonétique à Athènes au V siècle," Les imaginaries, II, Cause commune, I979, no. I, "IO/I8" (Paris I979) $345-68$, especially $35 \mathrm{I}-56$. Although we both stress the importance of Prometheus' immobility, Kerckhove emphasizes the effect of sensory deprivation. In his view this is central to the reorganization of perceptual reality, for it creates a mode of thinking that is now directed by the repression of the body and shifts away from oralaural participation to the more abstractive processes that he connects with phonetic writing: "Or c'est la tension entre la répression sensorielle et l'impossibilité de réagir physiquement qui permet à l'énergie de Prométhée de se concentrer dans une intériorité d'où s'échappe interminablement sa parole" (353f.). Stimulating as this approach is, it suffers from isolating only one factor in what is a complex movement toward the conception of an interiorized self in late archaic and classical Greece. If theatrical space, moreover, is in one sense analogous to the symbolic conventionality 
in the play seems to radiate. He imposes order and limit by means of his intellectual power- power that consists in the ordering, presenting, and withholding of knowledge.

At roughly the midpoint of the action, after Prometheus has enumerated at length his civilizing gifts to mankind, the cow-maiden Io enters. Zeus' lustful pursuit has driven her over the earth in confused wanderings. A figure of total disorientation, she utters inarticulate cries, does not know where she is, and is amazed that Prometheus knows her name. Their meeting is like the confrontation of oral and written mentalities. Io is immersed entirely in an immediate present beyond which she cannot see. She is surrounded by mysterious voices that drive her onward, and she is pursued by vague, dreamlike visions of the night that she can only partially discern and cannot understand. Following a journey that seems to hold neither end nor goal, she lacks the kind of centering and focusing of experience which Prometheus embodies in the play.

When Prometheus urges Io to "write down on the remembering tablets of her mind" the extent of her future travels (789), he provides her with both the temporal and the spatial organization that the ordering of reality by writing makes possible. In clear and well articulated order he indicates the definite stages in her journey. He orients her according to the directional marks of north and south, sunrise and sunset (cf. 79of., 796f.), just as he had oriented mortals by giving them the knowledge of seasonal limits and by teaching them how to read the signs and omens of the future from the birds (484-99). The verb "set on a path," hodoun, occurs in both passages $(498,8 \mathrm{I} 3)$ and marks the directional, orienting nature of the kind of knowledge which Prometheus gives to mortals.

Prometheus' spatial ordering of Io's movements by explaining the route of her wanderings has a temporal equivalent in the future of the places that she traverses. These nameless points, Prometheus says, will become famous in later times, fixed markers in a strange territory, because of her passage (e.g. $732-34,839-45$ ). He tells her also of the remoter end of her sufferings when she reaches her goal in the land of Egypt and of another kind of relief in the fact that one of her descendants will be his liberator. In the dimensions of both space and

of phonetic script, the Greek theatrical performance, with its multimedia and multisensory effects, is far from the abstractive result of sensory deprivation. 
Greek Tragedy: Myth and Structure

time, then, Prometheus gives her formless world a shape and a form, just as he gives her journey and her experiences a direction and a coherence. He makes available to her the organizing intelligence that comes with writing, coordinating past and future, tracing patterns in the shapeless mass of both space and time, and making patterns visible in the midst of a chaotic mass of unordered detail. He creates for the inarticulate half-human creature of suffering what is virtually a map of where she has been and where she is to go (we recall again that verb of orienting direction, "set on a path," hodoun, in 8I 3 ).

\section{IV}

Another exemplary text of this period has as its central theme the problem of organizing experience into knowledge and moving between different communicative and signifying systems, namely the Oedipus Tyrannus of Sophocles. Here even more sharply than in the Prometheus the problem of truth has to do with the crossing over between aural and visual modes of sorting and preserving information. It is commonplace to observe the importance of sight in the play. But less commonly observed is the interlocking of sight and hearing in many of Oedipus' statements about knowledge. When the primary object of inquiry arises in the prologue, namely the question of the death of Laius, Oedipus describes his knowledge of Laius as follows: "I know [of him] by hearing; for never have I seen him" (IOS). Since oida, "I know," is the first syllable of Oedipus' name, the line immediately associates Oedipus' knowing with seeing.

When Oedipus, near the end, blinds himself and returns to the stage, it is as a man returned to the one-dimensional knowledge of an oral/aural culture, reborn into a world dominated by the presence of sound as the primary mode of knowledge (I309f.): "Where in the earth am I borne, miserable? How does my voice fly around me, borne aloft?" (diapotatai phoradēn). The voice, phthonga, becomes something concrete and solid, a separate entity that has a quasi-corporeal reality, a locomotive power, like the Sphinx or like the magical, incantatory winged word in an oral culture. When he asks to close off the channels of hearing as of sight (1386-90), Oedipus restates in negative form the double sensory power that constituted the basis of knowledge in the prologue. In his anger and ignorance he 
accused the inwardly seeing Teiresias of being "blind in his ears" as well as in his "mind and eyes" (OT 37I). But Oedipus himself is exemplary of tragedy in his determined exploration of the interlocking of visual and auditory knowledge and in his awareness of the doubleness of verbal meanings in man's difficult search for truth. One thinks here too of Sophocles' contemporary, Empedocles, and his concern with the multiple avenues of knowledge through the senses. ${ }^{29}$

The ambiguity of language as a medium of truthful discourse implied in the Oedipus receives perhaps its most pregnant formulation in prose from the rhetorician and Sophist Gorgias near the end of the fif th century. In the Helen (c. I3) he evokes the power of language in the oral tradition to give pleasure (terpein) and persuade (peithein). 30 He distinguishes, however, between the "word written with artful skill," technei grapheis, and the word "spoken with truth," aletheiāi lechtheis. A fragment of his Epitaphios contrasts the "freshness" and "vitality" of actions with the "paleness" and "trembling" feebleness of letters (tremonta kai ōchra). ${ }^{31}$ Gorgias can still play upon alètheia as the truth communicated in the living interaction of the oral exchange, but with a major difference: he is conscious of being a scriptor who has written the logos of Helen (grapsai, Helen c. 2I) and therefore made a plaything or a fiction, a paignion (the last word of the Encomium on Helen) not a piece of "truth." "I wished to write my discourse," he concludes, "as an encomium for Helen and as a plaything of my own." His work, then, falls into the category of what is "written with art, not spoken with truth" (Helen c. I3); he is no longer a "master of truth." As a writer, he has a special consciousness of himself as the shaper of his own discourse, with the element of play that it can exemplify.

29. Empedocles 3 I B3, gff. (D-K); also B2.7f.

30. See C. Segal, "Gorgias and the Psychology of the Logos," HSCP 65 (I962) 99I 55, especially Io6f., I Iof., I 22ff.; W. J. Verdenius, "Gorgias' Doctrine of Deception," in G. B. Kerferd, ed., The Sophists and Their Legacy, Hermes Einzelschrift 44 (Wiesbaden I98I) I 2 If.

3I. For the text, see Friedrich Solmsen in Hermes 66 (I93 I) 249 n.2 (or his Kleine Schriften [Hildesheim I968] 2. I 59 n.2). 
Play is also freedom, the new freedom of the writer, detached from the public context of the oral performance, free of the responsibility of transmitting and recording the traditions of his people, able to develop ideas because they interest him alone. ${ }^{32} \mathrm{He}$ can follow his own path of words and thoughts with an independence not possible for the oral bard subject to the audience's control of the performance. This kind of author makes no claim to a transpersonal truth beyond himself. Unlike the oral poet, he knows the moment of his words' origin; he knows that they arise from within himself, that they are an object that he himself has fashioned and sees materialized as a text.

We may contrast with Gorgias' self-consciousness of writing the powerful affirmation of the truth of oral as against written statement a generation earlier in the Argive King's decree in Aeschylus' Suppliants (946-49), where spoken words have the solidity and tangible presence conveyed in the metaphor of the firmly fastened "peg" or "bolt" of his decree (gomphos, 945). 33 "These things are not written down on tablets," says the King, "nor sealed up in the foldings of scrolls: you hear the clear words of a tongue and a mouth that speak in freedom." But for Gorgias' younger contemporary, Thucydides, the relation between the spoken and the written word is just the other way around. The spoken word deceives and misleads and its seductive promise of pleasure (terpsis) in the agonistic context of recitation (Thucyd. I.22.I), whereas the written word is the result of effort (ponos) and investigation (zétésis) and yields accuracy (akribeia). Writing is surer than speaking in revealing what is hidden (to aphanes) behind surface appearances (phanera opsis, I. I0.2; cf. I.23.3-6). 34

The division in the philosophers, historians, and the tragic poets between surface and depth, appearance and reality, is encouraged by the special status of the written text in a hitherto oral culture. These authors have before them two models of mental organization. Oral

32. This play element has a notable role in Euripides' Bacchae. See C. Segal, Dionysiac Poetics and Euripides' Bacchae (Princeton 1982) 266ff.

33. On this passage and the solidification of speech as inscribed document see Turner, Athenian Books (note I 5) 9; also Longo, Tecniche della comunicazione (note is) I $22 f$.

34. On these passages see C. Segal, "Logos and Mythos: Language, Reality, and Appearance in Greek Tragedy and Plato," in Tragique et tragédie (note 24) 25-27; also B. Gentili and G. Cerri, Le teorie del discorso storico nel pensiero greco e la storiogra fia romana arcaica (Rome I975) 24f.; F. Solmsen, The Intellectual Experiment of the Greek Enlightenment (Princeton I975) 966 . 
communication faces outward, to the interactive contextual space between speaker and audience; written communication faces inward, toward the personal relation with the hearer. Its concern is syntactics rather than pragmatics. 35 As Aristotle points out in his discussion of the graphic and the agonistic styles, writing fosters the internal subordination of ideas within the syntax of the sentence. 36 Oral communication, on the other hand, depends less on the internal logic and structuring of the ideas than on the repeated assertions of its message, the fullness and copiousness of its style, qualitites that take account of the needs and limitations of the listener. The written message is far more enclosed in the autonomy of its own internal coherence. Some of the tensions explored by tragedy may be due to this pull between the inner cohesion of the written text and the other-directedness of the oral medium.

\section{VI}

The beginnings of such a tension coincide with the critical reflection on the mythic tradition which writing unquestionably aided. Around the middle of the fifth century Hecataeus of Abdera, like Thucydides, designates himself explicitly as a scriptor, the composer of a writing. His new graphic space fragments the prior vision of truth into a plurality of modes of understanding the world. 37 In the few fragments that survive of Protagoras' interpretation of Homer, we can see the same processes of distancing and critical examination: the copious flow, the forward-moving impetus, of the oral epic is interrupted after the first words. The fluid linkage of each phrase to the next is broken up into small, discontinuous fragments of discourse which can be scrutinized and dissected. It is the same technique that Aeschylus applies to the prologues of Euripides in Aristophanes' Frogs. 38

35. See Ong, Orality and Literacy (note 6) 37f., who cites T. Givón, "From Discourse to Syntax: Grammar as a Processing Strategy," Syntax and Semantics I2 (1979) $8 \mathrm{I}-\mathrm{I} I 2$.

36. Aristotle, Rhet. 3. I2, especially I 4 I 3b8-I 4 a 7.

37. Marcel Detienne, L'invention de la mythologie (Paris I982) I38ff., a propos of Hecataeus frag. I (Jacoby); see also Rösler (note I3) 306.

38. Aristoph., Frogs III9-I250; cf. Protagoras 80A28-29 (D-K), and C. Segal, 
For Democritus, perhaps at about the same time, even the numinous quality of poetic inspiration is linked to the written word: "Whatever a poet writes [graphei] with inspiration and the holy afflatus is indeed beautiful." 39 The power of a divine mind (theios nous) lies no longer in the gift of inspiration from the goddesses of memory but in a ratiocinative capacity, something like dialogic reasoning. 40 In the oral tradition it is the Muse and the goddess Mnemosyne who endow the poet with the power of lengthy, continuous utterance, made possible by a ready abundance of words and matter. The written word encourages density, concentration, discontinuity. Tragedy, in an intermediate position between orality and literacy, contains both tendencies: the flow of the long messenger speeches and the staccato effect of the dialogue, of ten marked by the sharp conflict of arguments in antilogiai and stichomythia. ${ }^{41}$

From the late sixth century on, critical reflection about the traditional tales gains momentum with writing. When variant versions can be fixed in a written text, discrepancies and contradictions are more easily detected. 42 The tragic poets-like Pindar, Hecataeus, Herodotus-do not merely repeat or retell the myths but reflect on them in a critical spirit. 43 In the graphic space that opens before the tragic poet as the writer of a fixed text, there opens also the autonomous space of the fictional, the possibility of free invention, though obviously within prescribed limits. Instead of being a master of truth, conveyer of multipersonal norms and values fixed in the conventionalized symbolic system of mythical tales recounted in heavily formulaic language, the poet is on his way to becoming the fabricater of fictions. Younger tragedians, Agathon, for example, even experimented, though rarely, with plots of their own invention. ${ }^{44}$ The task

\footnotetext{
"Protagoras' Orthoepeia and Aristophanes' 'Battle of the Prologues,', RhM II 3 (1970) I $58-62$.

39. Democritus 68 B I 8 (D-K).

40. Dialogizesthai, Democritus 68 B I 2 (D-K).

4I. See Solmsen, Intellectual Experiment (note 34) I 7 and 28ff.; also John H. Finley, Jr., "The Origins of Thucydides' Style," in Three Essays on Thucydides (Cambridge, Mass. I967) 74-82, I IO-I 2 .

42. See. J. Goody and I. Watt, "The Consequences of Literacy," in Literacy in Traditional Societies, ed. Goody (Cambridge i 968 ) 27-68, especially 44ff.; see also Svenbro (note 2) is.

43. Detienne, L'invention (note 37) chaps. 3 and 4; also Svenbro (note 2) I73-2 I 2. 44. Aristotle, Poetics I45Ibi9-26.
} 
of the tragic poet is now not to unveil reality but to create a selfconscious imitation of reality. 45

The Homeric interpretation of Theagenes of Rhegium at the end of the sixth century is an interesting forerunner of this kind of imitated universe of the art work. Our knowledge of Theagenes is pitifully scanty, but from the extant fragments it seems clear that he wrote a commentary on the Homeric poems, interpreting some of the more troublesome anthropomorphic features of the gods in an allegorical way. In this endeavor he had a predecessor in the Homeric criticism of Xenophanes earlier in the sixth century; but where Xenophanes only criticized, Theagenes seems to have allegorized. 46 To interpret a text, to reflect on it as an object apart from the context of its immediate performance, is to imply a second plane of truth. As a writing, such poetry no longer opens to a public world, fully visible to all and immediately comprehensible in the shared values that it utters and endorses. Instead, as a text, the poem reveals a hidden world that becomes visible only as we scrutinize the words as an object of contemplation. Its surface has to be lifted away or penetrated to reveal the deeper levels; it contains a thought that lies beneath the visible meaning (hypo-noia) or, in later terminology, says something other than its overt statement (all-êgoria). 47 With a written text, it becomes possible to distinguish a first level of meaning from a second, and there enters a critical distance that does not exist in a traditional society whose truth is firmly ensconced in the memory of its members. With the practice of writing, the true meaning of the traditional wisdom is hidden and invisible, something to be reached by that effort of intellect and abstraction which writing makes possible.

This is the kind of speech in which Thucydides is also engaged, far

45. See Rösler (note I3) 309ff.; J.-P. Vernant, "Le sujet tragique: historicité et transhistoricité," Belfagor 34 (I979) 639f., and "Naissance d'images," in Religions, histoire, raisons (Paris I979) I I I. Verdenius (note 30) I23f. points out the generally negative attitude toward poetry as fiction in early Greek literature.

46. The little that is handed down about Theagenes can be found in D-K I.5If. (number 8). If the tradition is reliable, he was a contemporary of Aeschylus and Pindar, and he "wrote" his comments down (grapsas, frag. 2 ad fin. and frag. 4). Something at least survived in writing for Hellenistic scholarship to pass on to late antiquity, from which come our only notices of his work. For Theagenes' Homeric interpretation and the implications of literacy see Detienne, L'invention (note 37) I 30.

47. The term hyponoia is probably pre-Platonic; allēgoria is late; see Svenbro (note 2) II 3-Is. 
more self-consciously. He rejects the fluid surface of Herodotus' discourse, still oriented to the oral context, 48 in favor of the more strenuous examination of evidence, comparison of divergences, abstraction, and inferences that all go along with writing. For the atomists Democritus and Leucippus, the phenomenal world itself is a text, a surface of appearances that has to be analyzed into its permanent but invisible truth of atom and void, the stoicheia, "elements," "letters," of its invisible atoms. ${ }^{49}$ To reach truth one must distance onself from the "human lifeworld" and plunge beneath this surface into the depths (buthos). 50 Such, mutatis mutandis, is also the investigative procedure of Thucydides: he seeks to recover the hidden causes that are aphanes, invisible, hidden behind the phanera opsis, the "visible appearance" (cf. I. IO, I.22-23).

\section{VII}

In a preliterate society, conflicts are acted out in social situations of encounter and exchange. ${ }^{51}$ So too, values are embodied in concrete, externalized objects - solid and visible points of reference for everyone. 52 With its distancing of experience and its removal from the necessity of face-to-face exchange in communication, writing encourages the internalizing of experience and the exploration of the private, the self-consciously personal. 53 The realm of the private, the personal, begins to appear. Conflicts are interiorized, and the whole inner world of the emotional life opens up. Phaedra's refusal to speak of her love, her reluctance to enter into dialogue with the Nurse and the women of Troezen, is symmetrical with the ambiguous silent speaking of the written tablets that she leaves for her husband.

48. For the predominance of the oral code in Herodotus see Longo, Tecniche della comunicazione (note Is) 72 n.26.

49. Leucippus 67 A9 (D-K) (or Aristotle, De gen. et corr. I. 3 I 5 b6ff.) and Lucretius, De rerum natura I. I 97f., 823-29, 2.688-99 are also evidence for the atomists' use of the letters of words as analogous to the atoms of things.

50. Democritus, $68 \mathrm{BII} 7$ (D-K). On the notion of truth in things beneath the surface and compounds of buthos in archaic poetry, see Svenbro (note 2) I I9-2I.

5I. See J. Russo and B. Simon, "Homeric Psychology and the Oral Epic Tradition," Journal of the History of Ideas 29 (I968) 483-98.

52. See L. Gernet, "La notion mythique de la valeur en Grèce," in L'anthropologie de la Grèce antique, ed. J.-P. Vernant (Paris 1968) 93-I 37.

53. See Ong, Orality and Literacy (note 6) I $78 \mathrm{f}$. 
The further development of writing increases the duplicitous potential of language. The gap between word and thing, logos and ergon, between what one says and what one is, becomes ever more evident and more problematical: compare Theseus' complaint of the deceptive discrepancy between men's voices (what they say) and their characters (what they are) in Hippolytus $925 \mathrm{ff}$. Language now is no longer the fullness of ready, serviceable stories that flow from the generous gifts of goddess memory; it becomes an ambiguous series of signs, traces, and absences. 54 Sophocles' Oedipus confronts language as a difficult track (ichnos) that he must follow out to the unknown end, like a hunter following the spoor of his prey (OT I08-II; cf. Ajax 5-ro). Muthoi and logoi, what men say to one another, lead no longer to an open road but to a narrow and difficult path. Parmenides' route is "outside the track of men." 55

The first reference to writing in Greek literature assigns to it the quality of ominous mystery as a sign. Such are the semmata lugra, baleful markings, what Bellerophon bears in the folded tablets intended to lead him to his doom (Il. 6. I68ff.). Yet even into the fourth century, writing is the distillation of the deceptiveness of language and the difficulty of communication. It can be a mark of prestige and a guarantor of accuracy and truth. 56 But a culture that still privileges face-to-face contact and immediate sensory experience also regards writing as an object of suspicion, the characteristic tool of guile and treachery. In Thucydides' account of the Spartan Pausanias' illicit dealings with the Persian king, letters are the mark of his secrecy; but the ephors, to whom he is betrayed by letters, are convinced of the man's guilt only when they see and hear for themselves. 57

Sophocles' Trachiniae and Euripides' Hippolytus (as well as the latter's lost Stheneboea) associate writing, trickery, concealed love, and female desire as all related distortions of truth. In tragedy, writing often serves as a motif or a figure around which the poet can

54. This point becomes explicit à propos of written language in Plato's famous myth about writing in Phaedrus 274c-276a. Building on Plato, Derrida works back from writing to all language as a protowriting.

55. Frag. 28 BI.27 (D-K): ektos patou.

56. E.g., Herodotus I.I25 or 3.I28; Thucyd. 7.8. See Longo, Tecniche della comunicazione (note I 5) 6If., 66f. $62 f$.

57. Thucyd. I. I 33. On this passage see Longo, Tecniche della comunicazione (note I 5) 
Greek Tragedy: Myth and Structure

crystallize the ambiguous attitudes of the culture toward the female and especially toward female desire.58 In the Hippolytus, writing appears as a duplicitous silent speaking that can subvert the authority of king and father. As a concentrated form of seduction and persuasion, such "female" writing is doubly a threat to the masculine ideal of straightforward talk and forthright action. 59

In the Trachiniae the letters that Heracles leaves behind for his family serve the father's goal of assuring the disposition of the patrimony after his death (46f., I $56 \mathrm{ff}$; cf. also I I66-72). But there is another kind of writing, the metaphorical bronze tablet that describes Deianeira's memorization of Nessus' instructions about what she believes to be a love charm (680-84). The metaphor deepens the theme of communication and exchange in this portion of the action, for the robe on which she smears the drug is sent to Heracles as her message of fidelity, a sign of faith of words (logōn pistis, 623). 60

This metaphorical writing essential to the transmission of the robe, along with the sexual charm that the robe supposedly contains, is a continuation of the Centaur's deceptive speech. The tablet expresses in a visual metaphor Deianeira's susceptibility to his ambiguous persuasion, with its erotic magic (710; cf. 660-62). It speaks a language of her unknown or unacknowledged self. As a silent remnant and record of the last words that Nessus addressed to her on the banks of his river, it shows Deianeira to herself as the exemplar of destructive female sexuality. It reveals the monstrous power of sexual desire that she can see in Heracles, Nessus, and Achelous but that she cannot recognize in herself. 61

In the interior space of the oikos, the woman's world, the open violence of the Centaur's masculine lust is transformed into feminine guile, persuasion, and seduction; and its murderous force operates through characteristically feminine arts. This baneful and mysterious power of female desire works not on the open, visible surfaces of the

58. We may recall here Gorgias' Helen, discussed above, which probably draws on tragic material (cf. frag. B23).

59. On women and writing as a joint object of suspicion, cf. Menander, frag. 702K, on which see Harvey, "Literacy" (note I 5) 62I; also Susan G. Cole, "Could Greek Women Read and Write?" Women's Studies 8 (I98I) I 37 and I 55.

60. For the theme of communication and exchange in the Trachiniae, see C. Segal, Tragedy and Civilization: An Interpretation of Sophocles (Cambridge, Mass. I98I) 94ff.

6I. For some implications of the tablet see Longo, Tecniche della comunicazione (note I5) 65f.; Page duBois, Centaurs and Amazons (Ann Arbor I982) 98f. 
Writing, Truth, and the Self

body but on the inner organs (I053-57). Its effects in these lines are described in metaphors of ingestion and digestion, processes involving the body as interior space, hollow, or vessel. It uses enclosure, enfolding, and immobilization rather than penetration (cf. I057). Heracles explicitly contrasts the wounds inflicted on him by the robe with the masculine weapons of war, the spear and the sword (I058, I063).

The metaphorical tablet is not only the negation of the patriarchal order implicit in Heracles' letters, but it is also the dark counterpart of the robe's intended message of wifely fidelity (492-95). It conveys a different message about the nature of women. Its perverted speech utters the feared and suppressed truth that the chaste wife is also a lustful female, that the bride of Heracles is also the woman who yielded to the Centaur's persuasion/seduction and might yield to the more overt sexuality of his animal nature. These themes extend far beyond the implications of the "writing of the brazen tablet" in 683; yet the implicit transformation there from speech to writing, voice to silence, force to guile, male to female desire is a focal point for the inversions of the social codes which tragedy of ten explores.

It is part of the multiple and shifting meaning that writing can have in this period that men can also send deceitful and death-bearing messages (Agamemnon in Iphigeneia in Aulis), and letters by women can bring salvation (Iphigeneia in the Taurian Iphigeneia; Andromeda in Euripides' lost play of that name). 62 In the political sphere, written laws are a safeguard against tyranny and the guarantee of fairness and equality under the Athenian democracy (Eur., Suppliants 429-37); yet the unwritten laws still enjoy the prestige of ancient tradition and sacral usage (Soph., Antig. 45off.; cf. Thucyd. 2.37.3).63 The combination of the practical, day-to-day utility of writing with its relative unfamiliarity and perhaps its Near Eastern origins doubtless encouraged such ambiguous, even contradictory meanings.

On the rational side, the practice of writing gradually transforms the invisible, quasi-magical power of the spoken word into a familiar,

62. Euripides is probably more open to these ambiguous associations of writing than Sophocles: see Longo, Tecniche della comunicazione (note is) 66.

63. On the relation of literacy and orality to the debate between written and unwritten law in the fifth century see Cerri, Legislazione orale (note is) especially chaps. 4 and 5; also Fabio Turato, "Seduzioni della parola e dramma dei segni nell' Ippolito di Euripide," Bollettino dell'Istituto di Filologia Greca, University of Padua, 3 (I976) I 8If. 


\section{Greek Tragedy: Myth and Structure}

material object, a well defined, clearly delimited human creation. 64 This concretization of language into writing gives an impulse to the study of language and communication per se. 65 Indeed, one finds a fascination with the origin and nature of language throughout this entire period, in the Sophists, in Thucydides, Herodotus, and the tragedians. All of the tragedians speculate on the origins of language and the origins of writing. A curious fragment of Euripides' lost Theseus shows a fascination with the physical form of letters (a character describes the shape of the letters that make up the name Theseus); and the popularity of the passage is indicated by the fact that it was closely imitated by two of Euripides' younger successors, Agathon and Theodectes. All three are interested in the physical form of letters as visual signifiers of the spoken word. 66 Such passages are indications of the new consciousness of the textuality of the work, operating at the microcosmic level of the basic act of composing shapes into language.

Instead of disappearing into the collective memory once the performance is over, being absorbed back into the communal voice, the written word of the poet has an autonomous existence apart from the spoken utterance that realizes it. The literate poet becomes even more aware than the archaic bard that his words are the component parts of an artistic product, a crafted object. His work is no longer a memorial to others' deeds, as in Homeric epic or even the archaic encomium, but a distinctive entity of his own, the guarantor of his own skill, not his patron's eternal fame. 67 Of the extant tragedians, Euripides most frequently uses this metaphorical crystallization of poetry as a monument or an artifact 68 - and also as a text.

64. See J. Goody, Introduction, Literacy in Traditional Societies (note 42) I: "Its [writing's] most essential service is to objectify speech, to provide language with a material correlative, a set of visible signs. ..."

65. See in general Longo, Tecniche della comunicazione (note I S) chaps. 2 and 3; Lanza, Lingua e discorso (note is) chap. I, with the bibliography, sof.

66. Eur. frag. 382; Agathon, frag. 4; Theodectes, frag. 6 (Nauck); see Harvey, "Literacy" (note is) 603f.

67. See Svenbro (note 2) I 86ff. on Simonides. Contrast passages like Ibycus 282.47f. (Page) or Theognis 237-54 with passages like Pindar, Ol. I. I I Iff. or Ol. 6. I-4 or Pyth. 6.7-I 8. For recent discussion of the poetics of sixth-century singers see Gentili in Vegetti (note 7) 53-76, especially 62ff., with the bibliography, $75 \mathrm{f}$.

68. See, for example, Alc. 962-7I; Med. I 90-203; Hipp. I I 25ff., I 428-30; Ion I I 4365; HF 673-95; see in general P. Pucci, "The Monument and the Sacrifice," Arethusa Io (I977) I65-95; also Segal, Dionysiac Poetics (note 32) 31 $8 \mathrm{ff}$. 
In tragedy, where the poet never speaks in his own person, this kind of self-conscious textuality can work only implicitly, behind the dramatic spectacle. To show how it may function, even where the play seems relatively unself-conscious about its own poetics, I shall examine briefly the climactic events in Sophocles' Oedipus Tyrannus (1237-96). The main actors are absent from the stage, and the dramatic enactment of the events is suppressed in favor of a long narrative account in the third person by an outsider, a new arrival, the second messenger who tells the tale. The Messenger begins by pointing out that he tells of things that were and are not seen: "There is [was] no vision present" (opsis ou para, I238). He thereby sets into relief the distinctive quality of the telling that takes place through the visual representation onstage. 69

Within the Messenger's narrative, memory itself has a spatial correlative in the penetration to the private, interior parts of the palace: first Jocasta's violent rushing inside the doors (pylai, 1244) to the place where she "has memory [makes mention] of the old seeding" from Laius (I246), then Oedipus' breaking through those doors (pylai, I26I) to find her body. Here, as in the Agamemnon or the Bacchae, the most memorable events of the play are revealed to us only in verbal narration: the suicide of Jocasta and the self-blinding of Oedipus. Sophocles is of course following the convention of Greek drama which demands that such violence be enacted offstage. But in calling specific attention to the contrast between dramatic enactment and narration, he also implies a new self-consciousness of the textuality of the work.

The Messenger's tale not only presents the visual contents of memory; it is also an emblematic account of memory's inner vision. Memory here becomes correlative with vision, a kind of nonvisual seeing just as writing is a nonoral speaking. It is also an interiorized seeing, and we may recall here the implications of the metaphorical writing on the tablets of the mind.

This memory of the Messenger conducts us, verbally, inside the

69. For a more detailed discussion of this passage, see C. Segal, "Time, Theater, and Knowledge in the Tragedy of Oedipus," Edipo: II teatro greco e la cultura Europea, ed. B. Gentili, forthcoming. 
gates of the palace where Oedipus rushes around in wild despair. Then it shows us the interior space of Jocasta's marriage chamber, the scene of her suicide and Oedipus' self-blinding. The narration, however, permits us to glimpse these most important events only in fragments, by significant absence rather than through the full presence of the actors or the enacted events. By calling attention to the fact that he is withholding the visual appearance of his chief protagonists in favor of a purely verbal narration, the poet also reveals his consciousness of the theatrical spectacle as a special form of narrative, mediating between external and interior vision, between visible, physical acts and the emotional world that they reveal.

The Messenger ends his long narrative with the words, "For these gates of the palace are opening; soon you will see a spectacle [theama] such that even the one who loathes it will feel pity" (I 295f.). The theatrical action, the visible opening of the outer doors of the palace, now mirrors the Messenger's verbal account. That recited narrative, based on a carefully structured text-words set down in advance to be delivered exactly as the poet has planned-has its own mode of revealing what is kept hidden. Its climactic moments too are the acts of closing and opening doors (I 244, I26If.; cf. I 287, I 294f.), but these acts take place entirely in the unseen, interior space within the palace.

Sophocles uses the conventional device of the messenger-speech with a new consciousness of the relation between the poet's text and the dramatic (visually enacted) events. He stresses the parallelism and the contrast between verbally describing the unseen events behind the palace and bedchamber doors and theatrically showing Oedipus as a spectacle on the stage (I295f.). Oedipus now emerges through the palace doors as the center of all attention and the object of pitiable sight to all. "O suffering fearful for men to see" is the immediate response of the chorus (I298). The terms for vision, spectacle, and the opening of gates shift between the narrator and the events he describes, the hideous violence that takes place behind closed doors. 70 Sophocles thus calls attention to the double mode of narration going on before us. He implies thereby the self-consciousness of the text that has plotted out the story in advance of the performance. The spectacle onstage has behind it a narrative of actions in which "there is no vision present" (opsis ou para, I238). The Messenger's purely

70. E.g., I238, I253, I 26I, I265, I287, I 294. 


\section{Writing, Truth, and the Self}

verbal tale is like the stage business before our eyes: it too is a way of opening doors to the hidden events that arouse our terror and our pity.

This textual self-consciousness, I suggest, owes much to the transitional moment of the form between oral and literate. This concern with the hidden, private, inner space, here and elsewhere in Greek tragedy, points to a poet-writer whose frame of reference is both the physical, public space of the oral performance in the theater and the graphic space of the text. This interior space of house or palace is, by the conventions of Greek drama, not represented on the stage but is always implicit behind the action. The poet composes for a stage that shows only the outside, but that exterior face of the represented world has a depth of meaning which derives in part from its hidden interior scene. That inner scene corresponds both to the emotional life of the characters and to the graphic space of the poet whose act of composition takes place before and apart from the public appearance in the theater where his words are given full realization.

The hiddenness of the tragic poet's text in the performance is the negative sign of something always hidden from view, on the other side of the palace wall, which is also the side of the Other. As poet/writer who manipulates real bodies in real space on the stage, the dramatist becomes sensitized both to the invisible graphic space of his text and to the hidden, interior space of the self. What is concealed behind doors and gates-the gates of the palace, of the mouth, or of the body-becomes the problem of his writerly art.

Greek tragedy has no word for the self. As John Jones, arguing from Aristotle's Poetics, maintains, tragedy concentrates on exterior forms and events, on mythos as a concatenation of actions, pragmata.71 Yet the sense of a self, of a complex inner life of motives, desires, and fears, is everywhere implicit. How does the tragedian make the inner life of the self visible? It appears not on the stage but in the behindthe-stage implied by the invisible text; something there but not representable, or representable only as a tension between the seen and the unseen. This interplay between interior and exterior space parallels

71. Poetics 6. I $450 \mathrm{a} 2 \mathrm{ff}$. John Jones, On Aristotle and Greek Tragedy (London I962), especially $24 \mathrm{ff}$., $35 \mathrm{ff}$., $4 \mathrm{Iff}$. I am not advocating return to post-Romantic psychologism but rather suggesting a way of looking at the vexed issue of character in Greek drama through posing the self as problem. Here, as elsewhere, the Greeks raise the fundamental questions of representing reality in art with exceptional clarity. 
the increasing awareness of the interior realm of the $p s y c h \bar{e}$, the individual personality, that develops in late fifth-century thinkers as Socrates and Democritus.

Euripides is more explicit than Sophocles about the operations of this new textual awareness and the interior life that it implies. The Hippolytus is perhaps his most interesting work in this respect. This play, so concerned with the dichotomies of visible and invisible, inner and outer purity, tongue and heart, also makes an explicit correlation between what is hidden behind the gates of the mouth and the gates of the palace and, furthermore, connects this movement between inner and outer with writing. ${ }^{72}$ The silent speaking of Phaedra's written tablets, left in the interior chamber where she hangs herself, proves to be more persuasive than the spoken utterances of face-to-face confrontation between Theseus and Hippolytus.

When the absent king returns to Athens, the scenic action stresses a double contrast, between interior and exterior space and between the silence of written speech and the sounds of words cried out in pain or anger. Theseus is surprised at the "shouting" and "heavy cry" from within (79of.), and he is indignant that "the house does not deem it worthwhile to open the gates and address me joyfully" (792f.). Told of Phaedra's death, he gives orders to open the "enclosures of the gates, in order that I may see the bitter sight" (808ff.; cf. 792f.). But when that inner scene is exposed (through the stage machinery of the eccyclema), it reveals the ambiguous speech-in-silence of the woman's tablets inside her chamber. Theseus responds (877-8I): “The tablet shouts, shouts things not to be forgotten. How shall I flee the weight of woes? For I am gone, utterly destroyed. Such a song, alas, have I seen crying forth through the writing." His repeated allusions to the barrier of communication between himself and the unspeaking corpse (e.g. 826f., 842) set off this anomalous speaking of the tablet (cf. 856-65). This utterance is something "not endurable, not speakable" (847 and 875).

The spatial movement between inner and outer through the gates of the palace $(793,808)$ now shifts to a metaphorical movement between oral and written in words that pass or do not pass through

72. I have touched on the interior/exterior contrasts in C. Segal, "Shame and Purity in Euripides' Hippolytus," Hermes 98 (I970) 278-99, and on possible connections with writing in "Tragédie, oralité, écriture," Poétique so (I982) I48f. 
Writing, Truth, and the Self

the gates of the mouth (stomatos pulai, 882). As a speech that does not pass through the gates of the mouth, writing is an ambiguous mode of communication; but here that stifled form of utterance does in fact "shout out" (877) with full communicative power. When Theseus first saw the tablet, he described it as "showing" and "saying" ( $s \bar{e}-$ ménai, 857; lexai, 865); now its oral force intensifies. In reply, Theseus cannot contain his cry of grief (882-86): "I shall no longer hold down in the gates of the mouth this thing of ill passage outside, a destructive evil. O city! Hippolytus has dared to touch my bed by force, dishonoring the holy eye of Zeus." The passage continues the collocation of visual and oral which pervades the scene (e.g. 865, 879). In contrast to the woman's enclosed chamber of the unspeakable crime stand the speaking out and showing forth of revealed crime to the public space overseen by the eyes of father Theseus and Father Zeus (886). As in the Oedipus, the Other Scene, the son's violation of the most sacred and most forbidden of interior spaces, is presented as a series of recessive movements to a closed interior; and here that interior is explicitly identified with the ambiguous graphic space between utterance and silence, concealment and revelation, containment and ejaculation.

Writing is a metaphor, as in the Trachiniae, for the deviousness that female sexuality brings into the world. Communication between Phaedra's realm of feverish desire inside the house and the males outside is by indirection. She addresses Hippolytus only by the intermediary of the Nurse, 73 and she addresses Theseus only through the silent speech of her writing. In her famous speech early in the play, resolving to die, she laments the confusion that surrounds the two forms of aidōs, shame or modesty, two meanings spelled with "the same letters" (386-88). ${ }^{74}$ Here, as in the case of her tablet, writing is the model for the ambiguities of language, because the possibilities of error and deception exist as opposite meanings slide into each other. From this source flows a whole series of confusions in the lives of the characters and in the value systems that impinge upon them. The clearly delineated roles and stable, univocal meanings of a traditional,

73. In the first Hippolytus, however, presumably followed in this respect by Seneca in his Phaedra, there was a face-to-face interview between the queen and Hippolytus.

74. For the grammata of 387 in relation to the problem of signs and language in the play, see Turato (note 63) pp. I63f. with note 25 . 
aristocratic society, with its emphasis on face-to-face contact, have been lost; instead, words and modes of behavior become paradoxical, and familiar boundaries no longer hold. Hippolytus is both bastard and well born (cf. I454f.); Theseus is the source of domestic and political order and also of violence, bloodshed, and impurity (cf. 34f.); Phaedra is both noble in her fame (eukleia) and shameless in her passion (cf. I 299ff.; also 7 I 5 ff.).

The later plays of Euripides show another kind of awareness of tragedy's power as a medium that doubles the mimetic capacity of the word by the physical mimesis of deeds acted out by three-dimensional figures on the stage. The long recognition scene between brother and sister in his Iphigeneia in Tauris is especially instructive in this regard. Orestes, after long wanderings, has landed in the remote barbarian land of the Taurians, who sacrifice strangers to Artemis. Iphigeneia, who has been supernaturally transported here at the moment of being sacrificed at Aulis by her father, King Agamemnon, is the priestess of the goddess and as such must prepare the new victims for the sacrifice. In the course of the long three-way dialogue between Iphigeneia, Orestes, and his companion, Pylades (576-826), the longlost brother and sister come to recognize each other. The medium of recognition is a discourse about messages and about the relative values of writing and speech as secure and accurate modes of communication. ${ }^{75}$ The context is also one of domestic ties that shift abruptly between the extremes of distance and nearness. The poet praises the written word, implicitly, for its capacity to span great distances and to communicate the living presence of love between those hopelessly separated. The abstract system of signs which constitutes writing enables even the total stranger to convey a message of intimate emotion. But through the paradoxes of Euripides' brilliant dramatic situation, that impersonal, generalized capacity of the written message is negated unexpectedly by the living, emotional power of the spoken word in a face-to-face, oral/aural encounter.

The written message is something concrete and physical, an object that may be carried, sent, given $(584,589-90,603,667)$. But as Iphigeneia warms to the emotional reality of what this medium of communication can achieve, she begins to endow it with a quasi-

75. The following discussion of the Iphigeneia in Tauris is drawn from "Tragédie, oralité, écriture" (note 72) I 49-5I. 
animate life. Instead of a "messenger" who would "announce" her

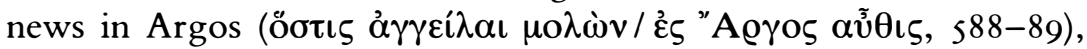
she describes the tablet itself as "speaking" and "announcing" ( $\delta \varepsilon \dot{\lambda}$ -

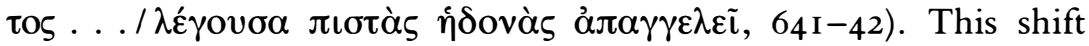
suggests the incommensurability between the physically circumscribed nature of the tablet as a tool or a means of conveying information in an impersonal manner and the rich human feelings attaching to the actual words that it contains. In reflecting on this paradoxical relation, Euripides allows Iphigeneia, carried away by emotion, to confuse the two.

That fusion deepens in a further complication that simultaneously affirms and destroys the power of the written word. The destined recipient of the written message in remote Argos proves to be the hearer to whom she is dictating it, standing right beside Iphigeneia in the Taurian land. This message, doubled by its oral, dictated form in order to prevent loss of the contents at sea, is simultaneously complete as both oral and written communication. When its intended bearer, Pylades, raises the problem of the tablet's loss at sea (755-57), Iphigenia replies $(762-65)$ :

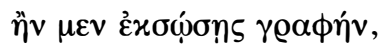

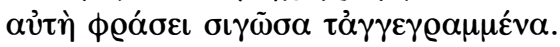

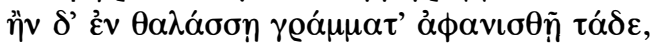

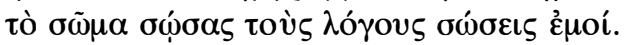

If you preserve the writing, itself, in silence, will speak what has been written on it. But if the writings are made invisible in the sea, in saving your body you will save my words as well.

These lines play upon the paradoxes of the visible-invisible and the silent speaking which we have noted in the Hippolytus. But here Euripides holds these paradoxes up to the shif ting lights of his kaleidoscopic art and gives them another turn. The written sign that marks absence turns into the means of recreating presence; now, however, it does so not through the deferred, abstractive, silent medium of writing but through a face-to-face oral/aural interchange. Thus the oral message, the reading aloud of the written text, intervenes to prevent the separation between brother and sister by the sacrifice-the sacrifice that this letter, like Phaedra's, implicitly sanc- 
Greek Tragedy: Myth and Structure

tioned, for its sending meant acquiescing in the sacrifice of one of the two Greek youths captured by the Taurians.

Orestes then dismisses the letters of the tablet, along with their distanced conveyance of communication in far-off lands, for an immediate hédone of touch and embrace, of tangible acts rather than words (793-94):

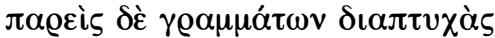

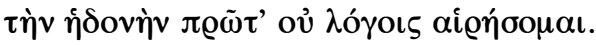

Letting go the folded letters (of the tablet), I shall take my joy not in words.

Harking back to Iphigeneia's words some seventy lines earlier, Orestes' gesture caps the ambiguity and incompleteness of communication by the written word. As Iphigeneia was about to consign the tablet to Pylades, she spoke of its presence as if it were a mythical being (727-29):

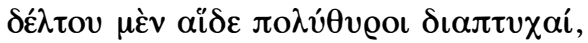

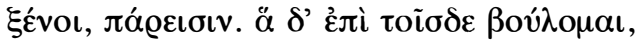

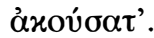

Strangers, the many-doored foldings of the tablet are present here. But as to what I wish in addition, do you hear.

But as the discussion of delivering the tablets at Argos goes on, the written medium wavers between reliability and unreliability (75565). Both qualities are functions of its tangibility and impersonality. The pull between strong verbs of direct, oral communication like "tell," "announce," "hear" (729, 753, 762, 769) and the giving or losing of letters $(745,756 \mathrm{f}$., $763 \mathrm{f}$.) with their anomalously silent speech (763), underlines that crossing between the two communicatory systems.

Euripides rings one further change on these shifts between written and oral at the end of the scene. Orestes, who receives the written message in an oral form, dismisses the grammata in favor of direct, physical gesture, as noted above (793-94). Yet his oral/aural perception and response prove insufficient. Iphigeneia has need of further 
proofs, tekmêria (808-22). These tekmēria (significantly, a word belonging to the rationalistic vocabulary of the Sophistic movement) brings us back from the technology of writing to the remote, quasimythical tales of the house of Atreus, the stories of the golden ram and the sun's stopping in its course, woven, not written, on the tapestries of a young girl in her house (8I I-I 7 ). They are, in fact, stories that Euripides himself artfully tells in the second stasimon of the Electra (669-746). Chronological relation between the two plays aside, this movement from letters to weaving bears on Euripides' own self-awareness of his art. He locates his tragic version of the myths between a newer, written technology of communication, indicated in the letters (grammata) of the tablet, and an older, more traditional form, symbolized by the age-old art of weaving, which is itself an ancient and traditional metaphor for the telling of tales in oral culture.

In his last play, the Bacchae, Euripides weaves the madness of Pentheus into a complex texture of illusionistic effects and places it in a precarious balance between seeming and being, hallucination and reality, which reflects the paradoxical status of the theater itself. Amid the visible presences and tangible actions, every event is also a form of illusion. 76 The god's visitation of madness upon his mortal victim becomes part of this tension between a subjective, distorted, private view of the world and the objective reality of the god's supernatural power.

The Bacchae problematizes the mask as the symbol of the god's power. In so doing it also problematizes the power of the theatrical spectacle to represent the hidden reality of the interior life, the subsurface beneath the mask. Dionysus in the play appears not only as the god of wine and religious ecstasy but also as the god of the mask and of the theatrical illusion embodied in the mask. ${ }^{77}$ The crisis of knowledge (and self-knowledge) is now framed as a theatrical crisis, that is, as a form of the question, How much and what kind of reality is contained in the fictional construction of the spectacle? Is there a truth hidden beneath the mask and beneath the act of wearing masks?

76. See my Dionysiac Poetics (note 32) 2 I5-7I. On this concern with appearance and reality in Greek thinking about art, see Vernant, Religions, histoires, raisons (note 45) I $28 \mathrm{ff}$.

77. See my Dionysiac Poetics (note 32) 2 I $5 \mathrm{ff}$, $223 \mathrm{ff}$,, $260 \mathrm{ff}$. 
Or, yet further back, What kind of truth can be claimed by a discourse whose origins are no longer sacred, no longer derived from the inspiration of the Muses, but lie entirely in the writer himself as the fabricator of a text whose very materiality attests to its human creation? The increasing pressure of these questions follows with that inexorable logic which pervades early Greek culture and is perhaps one of the factors responsible for the demise of tragedy as a creative form.

The Bacchae is among the last of these tragedies. A generation earlier, in Sophocles' Oedipus Tyrannus, the god, however mysterious, retains his Olympian otherness, the objective reality of his mysterious power. In the Bacchae the god enters the subjective play of disguise and role-playing on the tragic stage and is himself a kind of externalized projection of human fantasies, fears, desires. ${ }^{78}$ At its most optimistic, the last phase of Greek tragedy celebrates its power to create fictions. This more optimistic mood pervades the Helen of Euripides. ${ }^{79}$ At its most pessimistic, it calls attention to the airy bubble of its imagination, floating precariously in a world that no longer knows what reality is. In the terms of the Bacchae, the mask is an extension of the god's power, the sign of his ambiguous presence among men, forcing them to choose between illusion and ultimate reality; but it is also a human creation, the sign of man's power to shape fictions that may be only an emptiness behind the illusionistic covering.

\section{IX}

In a preliterate society, one knows what one can recall. What is useful, appreciated, valued, and therefore relevant is preserved and lives on the lips of men. The winners are remembered; the losers fade

78. For these concerns of late fifth-century drama see Helene Foley, "The Masque of Dionysus," TAPA I Io (1980) I07-33; Froma Zeitlin, "The Closet of Masks: Roleplaying and Myth-making in the Orestes of Euripides," Ramus 9 (1980) 62-77, and "Travesties of Gender and Genre in Aristophanes' Thesmophoriazusae," Critical Inquiry 8 (I98I) 30I-27, especially 309ff. I take a rather different view of the mask from Jones, On Aristotle (note 7 I) $43 \mathrm{ff} ., 59 \mathrm{f}$.

79. See below, chapter 7, "The Two Words of Euripides' Helen," ad fin.; also C. Segal, Dionysiac Poetics (note 32) 340ff. 
away. 80 The effect is what anthropologists have called homeostasis, a tendency to maintain the current values and modes of behavior by a kind of natural selection of what supports them. ${ }^{81}$ When Herodotus undertakes to preserve in writing what would otherwise become exitêla (I.I), that is, vanish into the detritus of the forgotten, he marks a new stage in Greek culture. When the tales about the past, the myths, genealogies, wise sayings, proverbs, laws, and instructions can be fixed definitively, in the form of writing, they can be scrutinized and criticized for discrepancies or contradictions. In a purely oral culture all the variants are true, that is, all have a claim to be heard simply because they are told, because they are living tales through which the society expresses its consciousness of itself. When men have the unsorted multiplicity of such tales crystallized in writing beneath their eyes, truth or accuracy becomes something to be adjudicated among conflicting or contradictory claims. Hecataeus may smile at the plurality of tales which he sets down in writing (grapho , $4 \mathrm{FI}_{\mathrm{I}} \mathrm{Jacoby}$ ), 82 but in the more serious mood of tragedy, conflicting claims on truth involve life and death.

While Hecataeus and Herodotus and to a far greater extent Thucydides were fixing in writing, for critical examination, the events of the recent past, the tragedians fixed in writing, for another kind of examination, the myths, the tales of gods and remote heroes, whose overt content is the distant past. Contemporary subjects, such as Phrynichus' Capture of Miletus or Aeschylus' Persians, are rare; and even such recent events gain a certain aura of mythical remoteness through the elevated language, the close presence of the gods, and the intervention of the supernatural in ghosts, omens, prophecies, and the like. Tragedy resembles the poetic narrative of an oral culture in that its concern is the present relevance of the myths it uses. These tales are remade to fit a homeostatic present with little concern for historical depth. Yet the quality of that mythical narrative is determined by the spirit of criticism fostered by writing. The myths told by tragedy are no longer the myths of an oral society, clear exemplars of a received truth or accepted communal values.

Innovation in mythical narration is the stock-in-trade of Greek

8o. See Ong, Orality and Literacy (note 6) $47 \mathrm{f}$.

8I. Goody and Watt (note 42) 3 I-34; see Rösler (note I3) 304.

82. See Detienne, L'invention (note 37) I 38. 
poets beginning with Homer. In tragedy, however, that innovation is more drastic, less predictable, and cuts more radically to the heart of the story's meaning. Attending a tragic performance, one could never be certain just how a given myth would be told. The surviving tragedies about Iphigeneia, Electra, and Orestes and what we know of Oedipus or Philoctetes in the three tragedians show how divergently a myth could be handled. And even a single tragedian could present quite different versions of the same subject, as Euripides does with the tales of Hippolytus and Phaedra, Orestes, Iphigeneia, and Helen.

Mythology, Marcel Detienne has argued, comes into being only with the crystallization of oral tales into the written form that fixes them as fictional stories, muthoi plasthentes, as Plato calls them. ${ }^{83}$ For Plato, whose battle against the mentality of the oral culture Havelock has eloquently traced in Preface to Plato, truth should be the property of the philosopher who enunciates the values and norms that had previously been in the hands of the poets. The philosopher is a writer; Plato, with whatever elaboration and malaise, writes down the conversations of Socrates. The philosopher rethinks and rebuilds from the ground up what had been diffused in the scattered tales, maxims, sayings, and paradigms handed down orally from generation to generation without critical examination. From this perspective, which is the perspective that the historical development of Greek culture has bequeathed to us moderns, myth appears as something remote and primitive to which we look with nostalgia and wonder, a mode of expression untampered with by the secondary elaboration of writing.

The oral culture of early Greece is mediated for us by writing, and the search for the preliterate substratum may be another form of Western man's perpetual longing for a primordial world of innocence and simplicity. 84 When writing becomes the major force not only in recording, but also in creating and shaping myth, we may be dealing with "l'illusion mythique" rather than with the genuine, first-degree myth of an oral culture; and access to a realm of pure myth, uncon-

83. Plato, Republic 2.377b; Detienne, L'invention (note 37) I 80.

84. D. Wesling, "Difficulties of the Bardic," Critical Inquiry 8 (I98I) 73 warns against the modern myth of the bardic, which is part of "print culture's nostalgia for oral culture." 
taminated by the reflective and distancing processes of recording them, becomes ambiguous, uncertain, and paradoxical. 85

Our own interpretation of Greek culture curiously recapitulates the experience of the Greeks themselves at the end of their great tragic age. As we take account of the controlling and reshaping power exercised by writing in forming the versions of the myths which come down to us as literature, as letters and by virtue of being preserved in letters, with all the absences that letters imply, we too are inevitably involved in the demystification and demythification of the mythical. We too become not merely hearers or even readers but interpreters, confronted with the paradox of a text that is forever fixed and forever elusive. The tragedians also, as writers, are not only mythicizers but the self-conscious interpreters of myth. It is important to recognize the complexities implied in their textual production and not idealize them, following Nietzsche's myth of tragedy's Dionysiac music and fusion with nature, as participants in the immediacy of oral vitality and the living, spontaneous power of primordial myth.

85. Detienne, L'invention (note 37) 226. 
